\title{
A Comparative Approach to Artificial and Natural Green Walls According to Ecological Sustainability
}

\author{
Alperen Meral ${ }^{1, *}$, Nermin Başaran ${ }^{2}$, Emrah Yalçınalp ${ }^{3}$, Ezgi Doğan ${ }^{4}$, Mehmet Kıvanç Ak ${ }^{2}$ \\ and Engin Eroğlu ${ }^{2}$ \\ 1 Department of Landscape Architecture, Faculty of Agriculture, Bingol University, Bingol 12000, Turkey \\ 2 Department of Landscape Architecture, Faculty of Forestry, Duzce University, Duzce 81620, Turkey; \\ nerminbasaran@duzce.edu.tr (N.B.); mehmetkivancak@duzce.edu.tr (M.K.A.); \\ engineroglu@duzce.edu.tr (E.E.) \\ 3 Department of Landscape Architecture, Faculty of Forestry, Karadeniz Technical University, \\ Trabzon 61080, Turkey; yalcinalp@ktu.edu.tr \\ 4 Department of Horticulture, Faculty of Agriculture, Bingol University, Bingol 12000, Turkey; \\ ezgidogan@bingol.edu.tr \\ * Correspondence: alperenmeral@bingol.edu.tr
}

Received: 15 March 2018; Accepted: 9 June 2018; Published: 13 June 2018

\begin{abstract}
Together with the rapid industrialization of the world, urbanization is also uncontrollably increasing. Such an increase in urbanization exerts the greatest pressure on natural resources, obligating people to live in intense structural spaces and increasing the need for green spaces in cities. Because of the expensive costs of horizontal surfaces being "green", urban places are faced with serious green-infrastructure problems. In recent years, alternatives have been searched for to eliminate such deficiencies. These alternatives, such as rain gardens, green walls (GWs), ecological designs, and green roofs, are commonly included in urban landscape designs. Besides rocky or steep-slope natural green walls (NGWs), natural green covers over buildings, walls, and so forth, structural members are also encountered in urban or rural places. On the other hand, artificial green walls (AGWs) have recently been used as a significant component of urban design. Although the AGWs are able to address various functional needs, they have not yet gained the desired popularity because of construction costs, static loads, constructional damages, and maintenance costs. In addition, such sites are largely left to exotic species with limited ecological requirements; these species are far from meeting ecological functions and resistance to extreme conditions. This study was conducted for a benchmarking assessment of artificial and natural green walls (A\&NGWs) with a high potential in urban landscape design not only for esthetics, but also for ecological and economical purposes. Plant species, initial establishment, maintenance costs, and some other parameters of selected GWs were assessed. The study was considered as pioneering research for low-cost minimum-maintenance AGWs to be included in urban landscape designs. It was concluded, on the basis of the present findings, that the GW systems established with natural plant species, rock, and other materials already existing in natural landscapes could be constructed at fairly low costs, and such wall systems could have great ecological contributions.
\end{abstract}

Keywords: vertical garden; green façade; wall vegetation

\section{Introduction}

People have had growing plants over walls by means of various techniques for centuries. Such an idea has become popular in today's urban spaces [1]. Köhler [2] indicated that the green areas of city centers should not be limited only to horizontal spaces but should be formed on other surfaces of buildings. This approach showed that vertical green systems would be more intense in urban areas. 
Rapid urbanization resulting from excessive population growth, migration to urban spaces, lack of planning and inspection, and fairly high costs of horizontal green spaces all produce disruptions to the existing historical, cultural, and natural heritage of urban places and gradually reduce the quality of life in these places [3,4].

In green walls (GWs), also called vertical gardens (VGs), plants do not occupy any space over the ground but cover large surfaces of buildings. Research shows that GWs reduce the urban heat island effect, prevent buildings from heat loss, reduce noise pollution, enhance urban biodiversity, create agricultural land, improve air quality, provide greenhouse gas emissions, leave a positive impression on people, add aesthetic value, and so on [5]. Such attributes clearly explain why GWs should be used to improve air quality and the lifestyles of urbanites. With accelerated urbanization, such GWs can also be used to grow edible vegetables for city dwellers [1].

GWs, proposed as a solution for significant ecological problems (air quality, greenhouse effect, microclimate, wild life, biodiversity, and noise pollution) experienced by mankind, are generally classified into three categories: green façade (GFs), bio-walls, and natural walls [3].

GFs are formed through growing winder and climber plants over a wall or supporting frame $[1,6]$. They are the most easily established of the vertical green systems [7].

Bio-walls, "living walls", are artificial environments supporting plant growth with special stainless steel containers, geotextiles, and irrigation systems [8,9]. In other words, instead of rooting beneath the wall system, living wall systems are formed by the plants being rooted and grown in special growth medium installed to the walls [7]. These systems can be designed for sunny and shady environments and tropical and temperate climates [10].

Different habitats of the earth provide living environments for various species and use the interactions between their attributes and the species in them. Walls are among these habitats. Although walls with their ecological characteristics do not necessarily serve as the ideal living environment for several plant species, they may provide a good living environment for various others [11]. Natural green walls (NGWs) generally form through plant growth and development over wall surfaces, particularly within the cracks and joints of walls [12].

GWs have various advantages, such as reducing urban heat island impacts; improving air quality; providing noise, heat insulation, and energy saving; and creating microclimates, biodiversity, agricultural land, and esthetic [11,13]. Despite all these advantages, they have various other disadvantages, such as the creation of static loads, structural damages, and high maintenance and construction costs [11]. In research done at Toronto University, a sample GW was built, and its effects in terms of decreasing the costs of air circulation, energy consumption, and cooling were proven. Moreover, this study helped to reduce the factors that have prevented vertical gardens from becoming widespread, such as lack of information, high cost, and technical problems with uncertainty and risk [14].

Jim [15] and Mattheck et al. [16] indicated that plants over wall surfaces do not grow to sizes exceeding the plant-biomass bearing capacity of the wall. The observations made on NGWs also proved this hypothesis, and such observations revealed that there were remarkable differences in growth and development of the same-age ligneous taxa (Ficus carica and Fraxinus angustifolia) grown over the walls or over the ground. GWs, with significant potential to be used for noise and heat insulation, can free buildings from the weight of installed noise insulation systems, mantling systems used for heating/cooling, and air-conditioners; thus they may not exert any additional loads on buildings [11].

The plant layer, which is the main element of an artificial green wall (AGW), consists of shrubs that do not have a pile root system. NGWs are usually composed of epiphytic plants [17]. Although the root systems of the majority of herbaceous species are not strong enough to create fractures and root systems of ligneous species may sometimes provide support for the load bearing capacity of walls, capillary corridors created by some species may be exposed to water conveyance and thus threaten the structural integrity of the wall. According to Doernach [18], a front cover composed of climbing 
plants did not create any damage to the plaster for more than 70 years; contrarily, it protected the plaster, and during that time frame, the plaster of the neighboring building was replaced three to four times [19]. In 1972, Grün stated that Hedera helix covered façade walls had been standing for 200-300 years [19].

The main reason this study was done was to try to understand why AGW applications are so limited and why their costs are high, according to many sources, while NGWs are very common, ecologically important, sustainable, and cost nothing. At this point, this study aims to ask an important question: Do AGWs have to be promotional items that should have normally been ecologically and economically sustainable but-given that essentially only a few hardy plant species are left over the world-that are economically far from being affordable for many people because of the need to keep the plants alive in such difficult habitats?

In the study, artificial GW types with the cheapest and most expensive setup costs under Turkey's conditions were put forward. From this, the inadequacy of green infrastructure in urban areas, which is one of the main problems, could be eliminated with less costs as a result of the wall vegetation constructed naturally. In this respect, it is revealed that the research is a solution to a major problem.

\section{Materials and Methods}

\subsection{Study Areas}

Because AGWs are quite cumbersome in terms of cost and maintenance, there are a limited number of them available, only in metropolitan cities. Considering this fact, these walls were selected from the interior spaces of İstanbul and its surroundings (Figure 1).

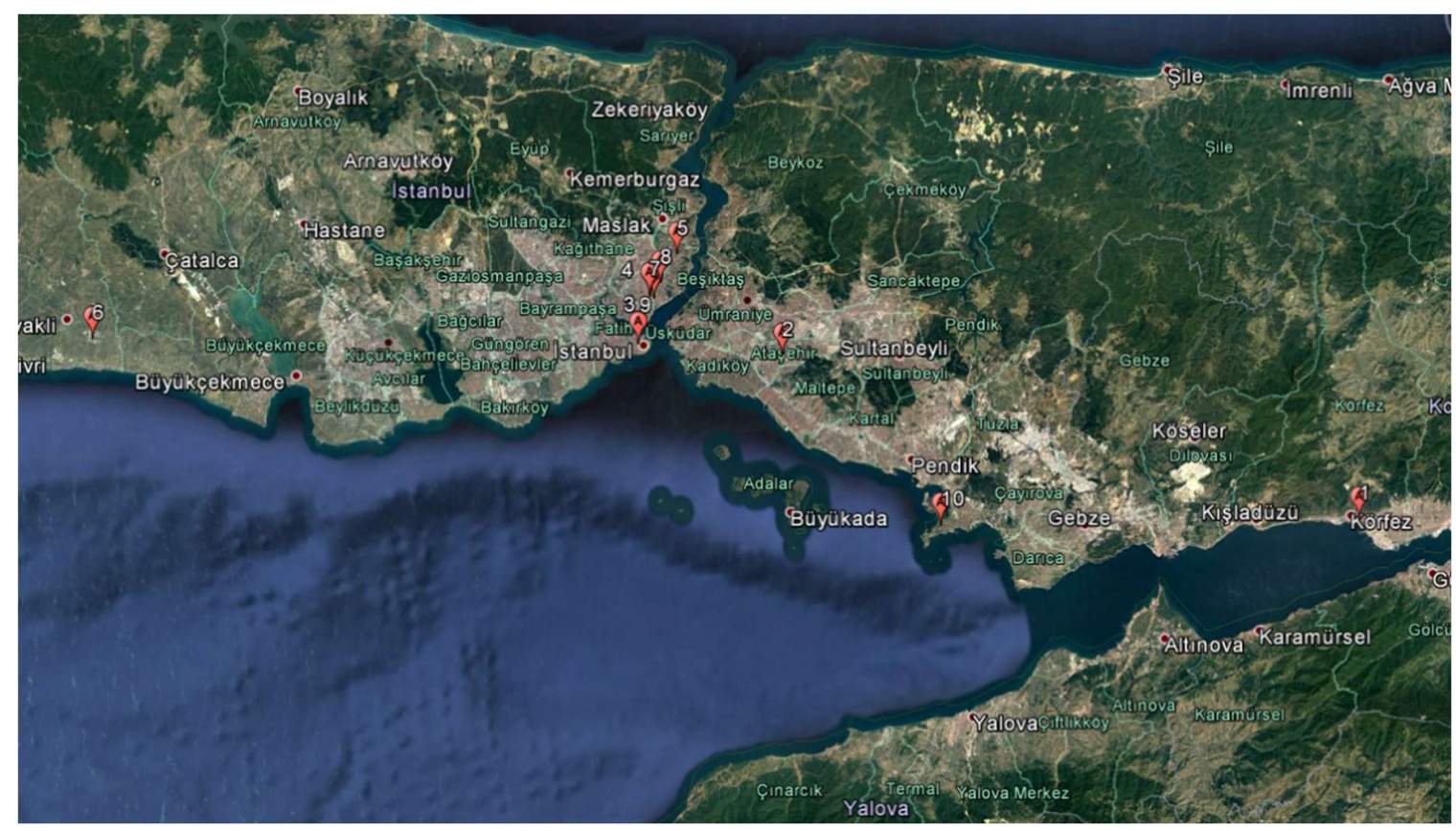

Figure 1. Artificial green walls included in this study.

Because the place and plant selection for AGWs are user-oriented issues, the place of implementation did not constitute an impediment for the study. NGWs were selected within the boundaries of Trabzon province by taking distinguishing characteristics of the vegetation (abundance, intensity, plant community, cover percentage, closure rate, and phenology) into consideration [20]. The geographical structure of the city was represented as much as possible while selecting the NGW; therefore the city center was selected as the center of the study area. While the walls in urban 
places and the vegetation of these walls were selected from Trabzon province, the walls in rural places to represent the above-mentioned structural integrity were selected from the eastern, western, and southern sections of the city center (Figure 2). In addition to the similarity between the climates of Trabzon and İstanbul, they also have component commonality in terms of their natural and cultural characteristics of urban landscapes. While AGW applications are more common in İstanbul because it is the largest city in Turkey, although Trabzon has a nominal population, it maintains its natural structure despite increases in urban development and has NGWs. These common and different aspects were important factors for selecting the study areas of these two cities.

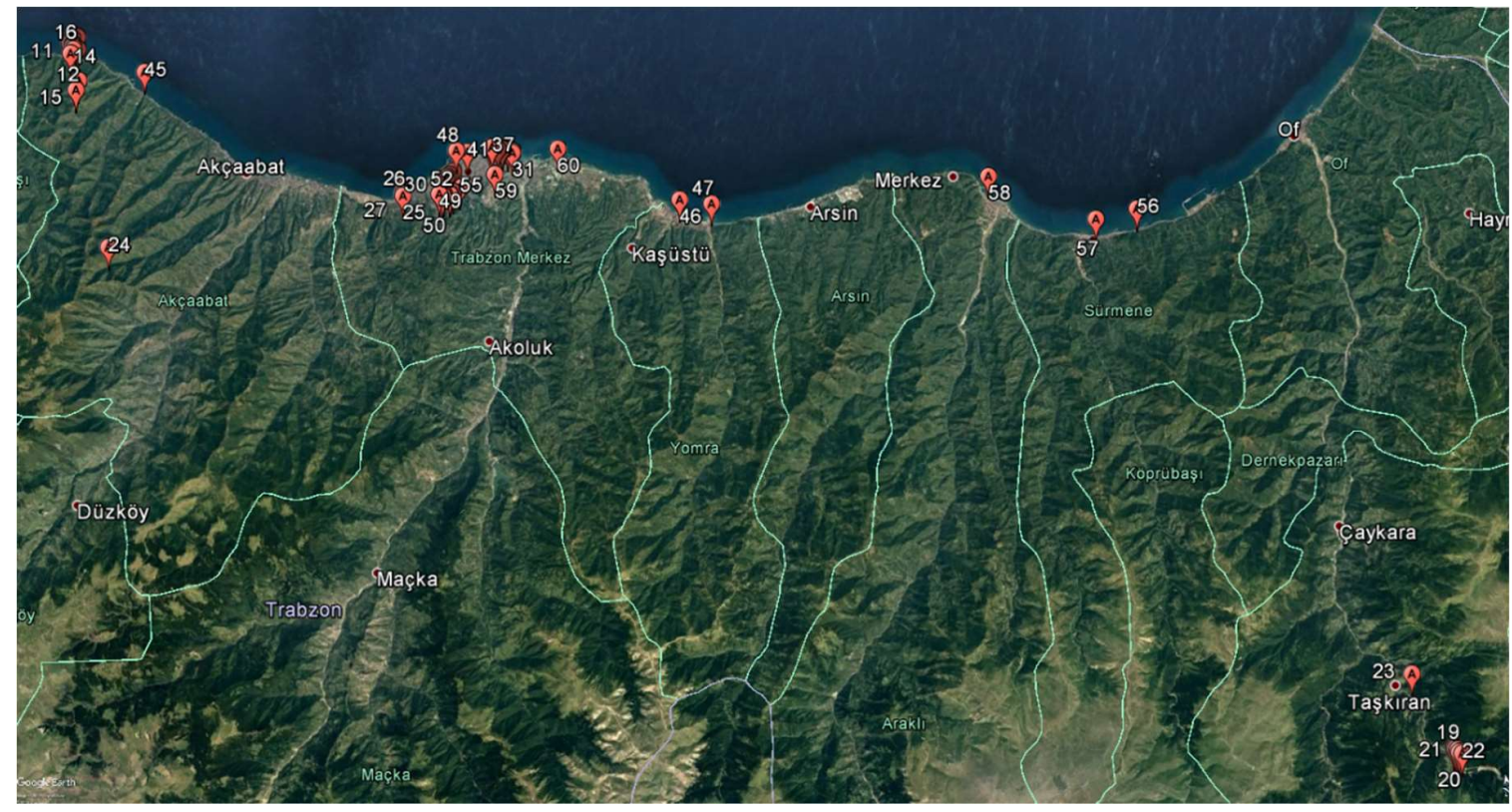

Figure 2. Natural green walls included in this study.

\subsection{Method}

The study was carried out in seven phases: literature review, site selection, in situ observations, vegetation diagnosis, visits to artificial wall companies, survey study (questionnaire), and statistical analyses. The general materials and method scheme are provided in Table 1.

Many of the natural wall vegetation studies were conducted in hot climates [21,22]. This study, conducted in a tropical, damp (Black Sea) climate, will provide an important benchmark data for Turkey. Jim's study [15], which is one of the most widely cited research studies in this field, discusses trees on stone walls in urban areas. Garden walls and walls in rural areas are usually made from easily available materials, and the structure of these walls allows plant growth [23]. Jim [24] mentioned three types of walls in his work in Hong Kong. These were masonry walls made up of irregularly sized stones, walls made of shaped stones, and walls made of stones covered with stones. Duchoslav's study [23], similarly to Jim's research, included walls with different features and functions. He attached different constructions, such as inline courtyard walls, fortifications, city walls, demolished building walls, and monumental walls. In this study, the walls were again examined under three categories. These were natural stone walls formed from irregularly sized stones, walls made of cement-based materials (briquettes), and concrete/reinforced-concrete walls. 
Table 1. Materials and method scheme.

\begin{tabular}{|c|c|}
\hline Aims & $\begin{array}{l}\text { * To determine to what extent green walls contribute to the quality of life by assessing the social and } \\
\text { psychological effects of the green walls on the cities' people. } \\
\text { * To determine plant species used in artificial green walls and their adaptations to the environment. } \\
\text { * To determine the system elements used in the green walls by observation. } \\
\text { * To investigate post-installation applications. } \\
\text { * To compare the vegetation on natural green walls and artificial green walls. } \\
\text { * To compare the sustainability and continuity of artificial green walls and natural green walls. } \\
\text { * To compare the maintenance and cost calculations for artificial green walls and natural green walls. }\end{array}$ \\
\hline Hypothesis & $\begin{array}{l}\text { * Green walls are an application that people want to see. } \\
\text { * The success of the green walls depends on the system elements and plants species. } \\
\text { * The applicability of green walls is in contradiction to the cost. } \\
\text { * The continuity and sustainability of green walls are possible. } \\
\text { * The green walls add naturalness and aesthetic qualities to the spaces they are in. } \\
\text { * Green walls have clear effects on the design of the areas they are located in. }\end{array}$ \\
\hline Materials & $\begin{array}{l}\text { * Natural and artificial green walls. } \\
\text { * Plant samples taken from the field, photos, and measurements. } \\
\text { * Interviews with artificial-green-wall application firms. } \\
\text { * Observations made in the field. }\end{array}$ \\
\hline Methods & $\begin{array}{l}\text { * Field studies. } \\
\text { * Questionnaire studies. }\end{array}$ \\
\hline Results & $\begin{array}{l}\text { * Properties of green walls. } \\
\text { * User trends. } \\
\text { * Values added to places green walls are located. } \\
\text { * Conclusion and evaluation. }\end{array}$ \\
\hline
\end{tabular}

In the studies conducted by C. Y. Jim [15], each wall contained one or more species of tree. Jim (1998) chose walls longer than $1 \mathrm{~m}$, with trees taller than $1 \mathrm{~m}$ and holding soil behind. In this study, all plant species were evaluated regardless of the length of the walls and the conditions of tree accommodation. In addition to carrier walls, bounding walls were also considered in the scope of the study. Jim [15] conducted his research in the summer months (three months), the primary growth season for plants. In this survey, land studies were carried out throughout the year. The most important reason was to ensure that the characteristics of the seasons (flower, fruit, and color) helped the diagnosis, minimizing the presence of plants that would be overlooked, particularly regarding the appearance and disappearance of herbaceous plants in a short time, to determine the seasonal differences between the walls from ecological and visual points of view. In the study by Jim [15], the walls were $200-400 \mathrm{~m}$ in length and $20-200 \mathrm{~m}$ in altitude. While most of the walls were highly or moderately damaged and looked to the north, which was the main slope direction, in this study, the walls chosen were $26-1192 \mathrm{~m}$ in length with a maximum altitude of $26-100 \mathrm{~m}$ ( 23 walls, $38.3 \%$ ).

Vertical gardens that cover surfaces of buildings with plants have emerged in different ways throughout history. Authorities consider that the ancestor of vertical gardening was the Hanging Gardens of Babylon. The inventor of the vertical garden concept was French botanist Patrick Blanc. Patrick Blanc proved that more than 2500 plants could live without soil and in low-light conditions. He also conceived the hydroponic vertical garden or living wall in 1994. This concept consists of a supporting profile, a watertight panel, felt, an irrigation and fertilization system, drainage canals, growing media, a lighting system, and a drainage chamber [25].

In spite of the fact that green vertical surfaces, particularly in urban areas, are regarded as ecologically important, AGWs often require irrigation systems and special nutrient solutions, and they cost more than the average amount that most people can easily afford. Thus, this study aims to focus on how NGWs can benefit from their superior relatives AGWs in urban areas, as these are more sustainable and free in cost. 


\subsection{Vegetation Identification and Diagnosis}

Plant samples were collected within the scope of field work for identification of the vegetation pattern of the GWs. Samplings were performed from 70 sites. A floristic analysis method, the Braun-Blanquet method, was employed for identification of the plants used in GWs $[20,26]$. The existence of the plants over sampling sites (cover-abundance), intensities, and cover ratios were determined, and species were collected for identification. The study was carried out between the years 2015 and 2017, and samplings were initiated at the beginning of vegetation in February, lasting until the end of November. Samples to be identified were preserved in herbarium.

Plant samples were dried in accordance with herbarium techniques and were made ready for identification. The samples were then identified at a laboratory with a stereomicroscope.

\subsection{Database Design and Statistical Analyses}

Following the field work, selected walls were assessed on the basis of certain criteria, and a database was formed. Selected AWG photographs were laid in a questionnaire before participants. In this study, the landscape quality of GWs was measured by a visual evaluation method. Penning ve Rowsel [27] and Misgav [28] stated that "the answers given by the users in the quality and visual evaluation of the landscape are right and good". Pairs of opposite adjectives, by the semantic differential scale technique developed by Osgood et al. [29], were presented to the participants in that study, who were asked to mark options they deemed appropriate. Generally, in the questionnaires, the answer scale was divided into five groups $(-2,-1,0,1$, and 2$)$ for the questions directed to adjective pairs. A ( - ) value indicated the negative group; a (+) value indicated the positive group. Ozgen [30] preferred a 5 scale with the roadside perception [31]. In this study, in order to make it easier to process the data, values of $1,2,3,4$, and 5 were chosen instead of $-2,-1,0,1$, and 2 .

Resultant data were then subjected to statistical analyses with SPSS 22 software (IBM, Armonk, NY, USA), and the results are presented in tables and figures. Correlation and regression analyses were performed to determine the relationships between participant characteristics, visual variables, and attribute characteristics. Standard deviations and arithmetic means were calculated to determine the visual landscape preferences of the participants. A quantitative research method was preferred to prove the relationships between the variables and to establish relations of causality. In brief, verbal and visual values were expressed and assessed in numeric values.

\section{Research Findings}

\subsection{Physical Characteristics of Selected Green Walls}

Two different types of GW were considered in this study: AGWs and NGWs.

Of the 10 interior GWs visited and in situ assessed, 8 of them were applied as hydroponic green wall (HGW) systems. The HGWs were generally composed of a support system, bearing system, growth medium, drainage system, irrigation system, and lighting system. While metal bearing members were used in nine of the AGWs, medium-density fireboard (MDF), largely containing wood but being more resistant to moisture than the wood, was used in one of them. Support members of the walls were made of PVC (Polyvinyl Chloride). While felt growth mediums were used in nine of the AGWs, a felted modular structure was identified in one of them. Automatic irrigation systems were available for nine walls without available drainage canals, and one of them did not have an irrigation system. While there were misting systems for two walls, only one wall had a lighting system.

The NGWs were selected from two different types of ecological formations, urban and rural, so as to represent the entire vegetation of the region. The NGWs selected had three different wall materials to determine the effects of wall materials on the vegetation over the walls. A total of 60 NGWs (30 from urban and 30 from rural sections) were selected on the basis of exposure (aspect), altitude, sunshine duration, age, anthropogenic impact, total area, wall materials, front and reverse ecological functions, and vegetation. Of the selected NGWs, 16 were made of concrete-reinforced concrete, 40 were made of 
natural stone, and 4 were made of brick. The ecological formation behind the wall was structural in 9 of them, urban green in 17 of them, natural green in 28 of them, and agricultural field in 6 of them.

Available water behind the wall should reach the wall's surface for better development of the vegetation. Therefore, the joints of the walls were also included in the study. While there were no joints in 17 of the walls, 39 had closed joints and 4 had open joints. Weep holes (barbicans) are also considered as another water conveyance system. While there were weep holes in 40 walls, 20 of them did not have weep holes.

While 16 of the walls had a sunshine duration of $0-2 \mathrm{~h}, 13 \mathrm{had} 2-4 \mathrm{~h}, 20$ had $4-6 \mathrm{~h}, 7$ had $6-8 \mathrm{~h}$, and 4 had $8-10 \mathrm{~h}$. While 20 of the walls faced north (exposure), 19 had east exposure, 11 had west exposure, and 10 had south exposure.

\subsection{Results for Vegetation Material of the Present Walls}

Plant materials of artificial and natural green walls (A\&NGWs) were assessed on the basis of their families, species, life forms, and naturalness in the province. Plant life forms were assessed through the Raunkiaer life-form classification (Table 2).

Table 2. Raunkiaer life-form classification system [4,32].

\begin{tabular}{ccc}
\hline Life Form & Location of Parent Tissue & Plant Types \\
\hline Phanerophyt & $>0.5 \mathrm{~m}$ & Trees and tall shrubs \\
\hline Chamaephyt & $0-0.5 \mathrm{~m}$ & Small shrubs and herbs \\
\hline Hemicryptophyt & Soil surface & $\begin{array}{c}\text { Prostrate shrubs or herbaceous } \\
\text { plants that dieback each year }\end{array}$ \\
\hline Crytophyt (geophyte with rhizome) & In the soil & Rhizomatous grasses \\
\hline Crytophyt (geophyte with bulb) & In the soil & Bulb-forming herbs \\
\hline Therophyt & Seed & Annuals \\
\hline
\end{tabular}

Of the selected AGWs, 19 different varieties of 41 different species and 23 different families were identified. The most common family for the walls was identified as Araceae (25\%). While 58 of the identified plant species $(96.665 \%)$ were exotic for the province, only 2 species $(3.34 \%)$ were indigenous to the research province (Figure 3).

Of the NGWs selected for this study, 72 different species of 34 different families were identified. The most common family over this kind of GW was identified as Asteraceae (16.43\%). Of the identified plant species, 64 species $(87.67 \%)$ were indigenous to the research province, and 9 species $(12.33 \%)$ were exotic for the province (Figure 3 ).

With regard to the life forms of the plants identified over the AGWs, only 1 of them (1.66\%) was a geophyte, 12 (20\%) were phanerophytes, and 47 (78.34\%) were hemicryptophytes (Figure 4$)$.

With regard to life forms of the plants over the NGWs, $8(11.1 \%)$ were chamaephytes, $14(19.44 \%)$ were cryptophytes, $3(4.19 \%)$ were geophytes, 39 (54.13\%) were hemicrytophytes, 5 (6.94\%) were phanerophytes, and $3(4.19 \%)$ were therophytes (Figure 4$)$. 


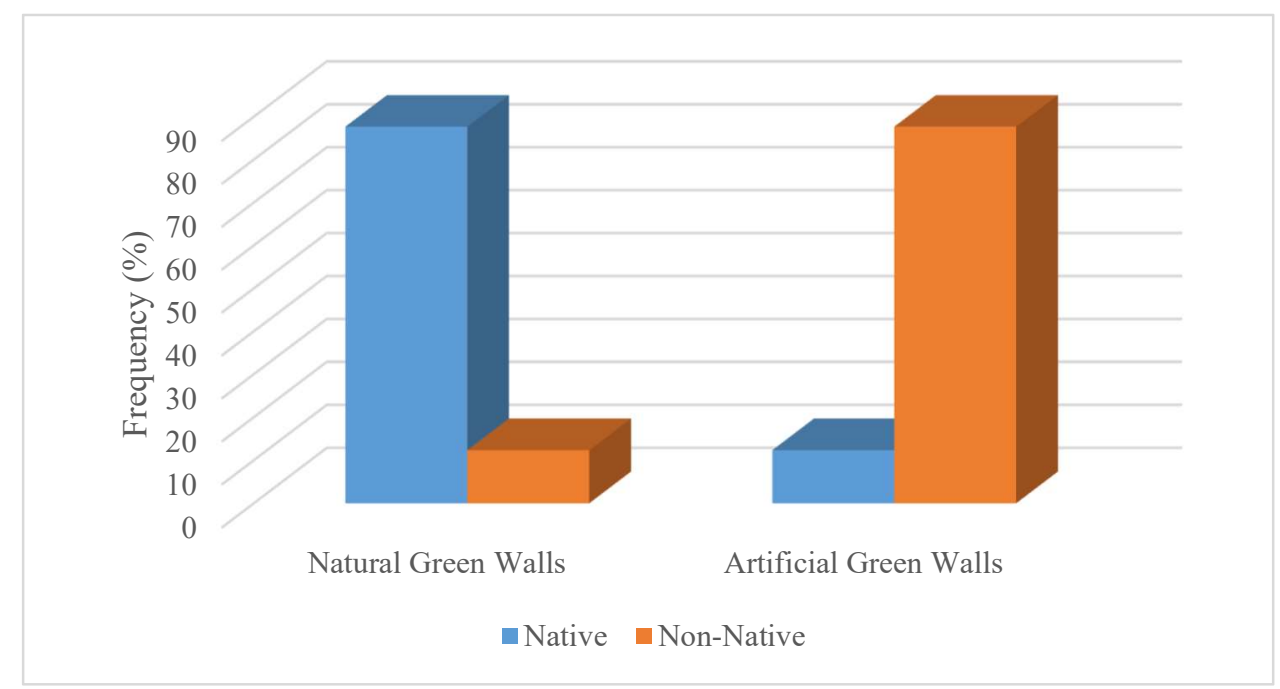

Figure 3. Naturalness of the plants identified for green walls.

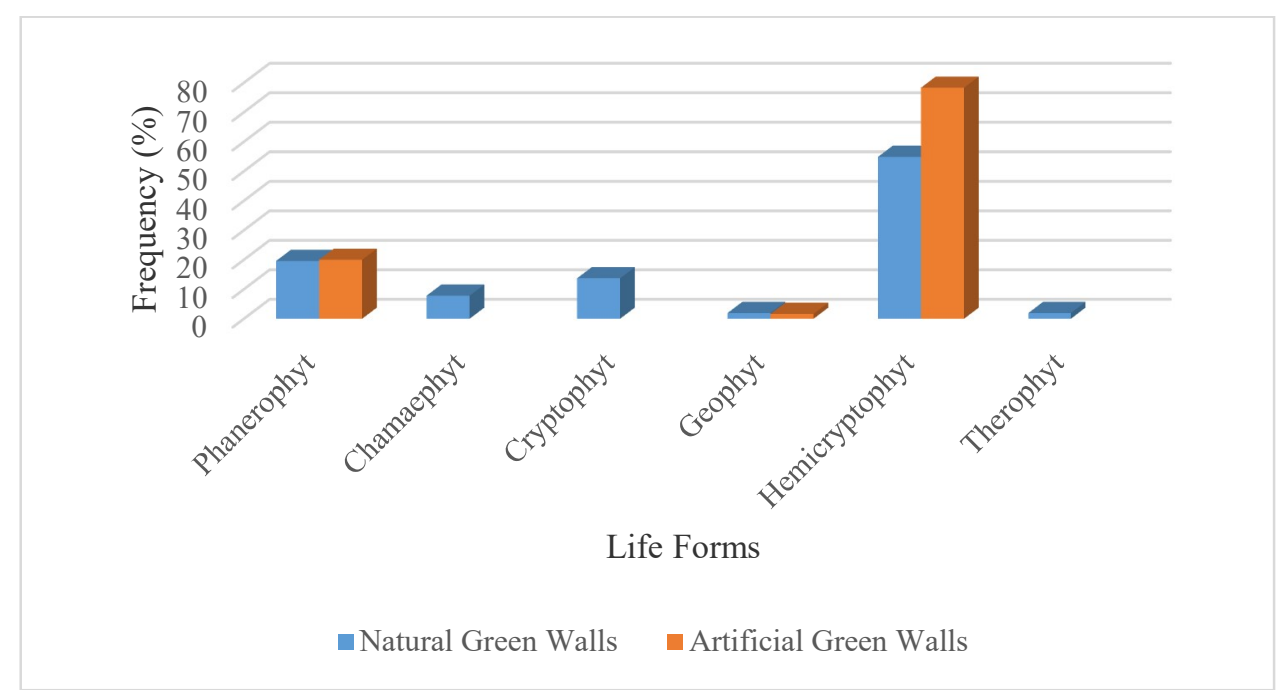

Figure 4. Life forms of the plants identified over green walls.

\subsection{Results for Maintenance Status of the Selected Green Walls}

Maintenance is significant issue for sustainability of the AGWs. Fertilization, lighting, and irrigation systems should be designed to meet nutrient, light, heat, and water requirements of the plant species. Maintenance costs of AGWs include monthly fertilization, irrigation, lighting costs, and the costs of general plant-maintenance practices, according to the findings obtained by searching the company that designed GW care. According to the information obtained from the landscape-maintenance companies (10 units), the average maintenance cost per square meter varies between $€ 50$ and $€ 60$ per month. However, in NGWs, these costs are nearly zero, as plant species emerge under proper vegetation conditions.

The problems experienced with the AGWs of the present study can be summarized as follows.

Generally, irrigation and relative humidity problems were encountered in AGWs. Under water and moisture deficiency, swells, blasts, paled leaves, sagging leaves, early flower falls, total die out of plants, and similar symptoms were observed. Under deficit light conditions for an AGW, defoliation of old leaves; weak, light-color, soft new leaves; thin and long branches toward the light source; and small flowers or non-flowering symptoms were observed. 
However for the NGWs investigated in this study, plant species continuously regenerated because of vegetation durability, and all the species were indigenous species already adapted to the region in which they existed.

\subsection{Results for Visual Aspects of the Green Walls}

In order to determine how the participants perceived the examined GWs, they were asked questions, and the arithmetic mean of the answers was taken. WGs were assessed by the users, and arithmetic means are provided in Table 3. Thus, the visual perception parameters of the GWs were measured.

Table 3. Arithmetic means for assessment of visual aspects.

\begin{tabular}{|c|c|c|c|c|c|c|c|c|c|c|c|c|c|c|c|c|c|}
\hline \multirow{2}{*}{$\begin{array}{c}\text { Photo } \\
\text { No. }\end{array}$} & \multicolumn{17}{|c|}{ Visual Evaluation Variables } \\
\hline & $\mathbf{M}$ & $\mathbf{a}$ & $\mathbf{b}$ & c & d & e & f & g & $\mathbf{h}$ & 1 & i & $\mathbf{j}$ & $\mathbf{k}$ & 1 & $\mathbf{m}$ & $\mathbf{n}$ & $\mathbf{o}$ \\
\hline \multirow{2}{*}{1} & $\mathrm{M}$ & 3.28 & 2.94 & 3.46 & 3.10 & 3.21 & 2.50 & 2.29 & 2.53 & 3.74 & 2.09 & 3.61 & 3.13 & 3.29 & 3.62 & 3.46 & 2.86 \\
\hline & S.D & 1.14 & 1.26 & 1.30 & 1.07 & 1.07 & 1.12 & 1.13 & 1.17 & 0.97 & 1.09 & 1.22 & 1.32 & 1.10 & 1.08 & 1.04 & 1.09 \\
\hline \multirow{2}{*}{2} & M & 4.05 & 3.98 & 4.12 & 4.36 & 4.09 & 3.22 & 2.26 & 3.90 & 3.99 & 2.15 & 3.97 & 3.26 & 3.94 & 3.85 & 4.01 & 3.57 \\
\hline & S.D & 1.01 & 1.01 & 1.08 & 0.85 & 1.05 & 1.26 & 1.21 & 1.20 & 0.93 & 1.18 & 1.17 & 1.26 & 1.06 & 1.11 & 1.11 & 1.03 \\
\hline \multirow{2}{*}{3} & $\mathrm{M}$ & 3.71 & 3.50 & 3.94 & 3.93 & 3.60 & 2.76 & 2.58 & 3.14 & 3.75 & 2.57 & 3.63 & 2.78 & 3.51 & 3.44 & 3.53 & 3.29 \\
\hline & S.D & 1.03 & 1.13 & 1.02 & 1.12 & 1.18 & 1.26 & 1.32 & 1.31 & 1.08 & 1.30 & 1.18 & 1.20 & 1.15 & 1.20 & 1.16 & 1.06 \\
\hline \multirow{2}{*}{4} & $\mathrm{M}$ & 4.15 & 4.08 & 4.06 & 4.36 & 4.12 & 4.33 & 2.91 & 3.97 & 4.14 & 2.33 & 4.11 & 3.29 & 4.11 & 3.79 & 4.06 & 3.66 \\
\hline & S.D & 0.96 & 0.93 & 1.04 & 0.76 & 1.01 & 0.91 & 1.40 & 1.02 & 0.89 & 1.23 & 1.00 & 1.27 & 1.01 & 1.04 & 1.13 & 1.02 \\
\hline \multirow{2}{*}{5} & $\mathrm{M}$ & 3.08 & 2.85 & 3.18 & 2.92 & 2.80 & 3.09 & 2.78 & 2.16 & 3.17 & 2.41 & 3.28 & 3.11 & 2.92 & 3.46 & 3.15 & 2.84 \\
\hline & S.D & 1.14 & 1.17 & 1.22 & 1.19 & 1.21 & 1.26 & 1.30 & 1.21 & 1.17 & 1.18 & 1.39 & 1.24 & 1.30 & 1.12 & 1.27 & 1.28 \\
\hline \multirow{2}{*}{6} & $\mathrm{M}$ & 4.07 & 4.03 & 4.04 & 4.15 & 3.88 & 3.86 & 2.47 & 3.41 & 3.97 & 2.28 & 3.99 & 3.66 & 4.01 & 3.98 & 4.16 & 3.73 \\
\hline & S.D & 0.99 & 0.95 & 0.98 & 0.98 & 1.15 & 0.99 & 1.17 & 1.07 & 0.89 & 1.19 & 1.07 & 1.10 & 1.04 & 0.93 & 1.07 & 1.03 \\
\hline \multirow[b]{2}{*}{7} & $\mathrm{M}$ & 3.93 & 3.70 & 3.79 & 3.75 & 3.54 & 3.39 & 2.53 & 3.31 & 3.90 & 2.34 & 3.80 & 3.48 & 3.51 & 3.68 & 3.80 & 3.23 \\
\hline & S.D & 0.95 & 1.02 & 1.00 & 1.06 & 1.07 & 1.06 & 1.18 & 1.15 & 0.86 & 1.17 & 1.04 & 1.06 & 1.17 & 0.98 & 1.01 & 1.11 \\
\hline \multirow{2}{*}{8} & $\mathrm{M}$ & 4.25 & 4.16 & 4.12 & 4.24 & 4.03 & 3.87 & 2.46 & 3.86 & 4.08 & 2.29 & 4.07 & 3.56 & 4.05 & 3.96 & 4.19 & 3.70 \\
\hline & S.D & 0.98 & 0.96 & 1.14 & 0.99 & 1.02 & 1.13 & 1.25 & 1.24 & 0.99 & 1.28 & 1.12 & 1.11 & 1.05 & 1.00 & 1.03 & 1.12 \\
\hline \multirow[b]{2}{*}{9} & $\mathrm{M}$ & 2.62 & 2.60 & 2.69 & 2.74 & 2.77 & 3.46 & 3.20 & 2.18 & 3.04 & 2.35 & 2.91 & 2.93 & 2.63 & 3.16 & 2.59 & 2.64 \\
\hline & S.D & 1.10 & 1.19 & 1.15 & 1.25 & 1.21 & 1.21 & 1.34 & 1.17 & 1.23 & 1.14 & 1.39 & 1.14 & 1.25 & 1.23 & 1.25 & 1.21 \\
\hline \multirow{2}{*}{10} & $\mathrm{M}$ & 4.09 & 3.95 & 4.14 & 4.23 & 4.08 & 4.35 & 3.46 & 3.59 & 3.95 & 2.61 & 3.91 & 3.26 & 3.84 & 3.54 & 3.90 & 3.54 \\
\hline & S.D & 1.10 & 1.16 & 1.10 & 0.95 & 1.21 & 0.87 & 1.40 & 1.31 & 1.11 & 1.31 & 1.16 & 1.20 & 1.20 & 1.15 & 1.13 & 1.15 \\
\hline
\end{tabular}

Considering the arithmetic means of visual aspects, it was observed that the naturalness and relaxing perceptions for the AGWs increased as their size $\left(\mathrm{m}^{2}\right)$ increased. Increasing size and diversity strengthened the esthetic perception of the walls (Table 4). 
Table 4. Correlations between visual aspects and attribute characteristics.

\begin{tabular}{|c|c|c|c|c|}
\hline Participant Features & 1 & 2 & 3 & 4 \\
\hline a & 0.015 & $0.177^{* *}$ & $0.181 * *$ & $0.351 * *$ \\
\hline b & 0.033 & $0.148^{* *}$ & $0.193^{* *}$ & $0.358^{* *}$ \\
\hline c & -0.003 & $0.185^{* *}$ & $0.199 * *$ & $0.425^{* *}$ \\
\hline d & 0.052 & $0.159^{* *}$ & $0.199 * *$ & $0.425^{* *}$ \\
\hline e & 0.059 * & $0.155^{* *}$ & $0.206^{* *}$ & $0.325^{* *}$ \\
\hline f & $0.197^{* *}$ & -0.017 & $0.291^{* *}$ & $0.216^{* *}$ \\
\hline g & $0.128 * *$ & $-0.065 *$ & $0.097 * *$ & 0.008 \\
\hline h & $0.076^{* *}$ & $0.115^{* *}$ & $0.259^{* *}$ & $0.391 * *$ \\
\hline 1 & 0.004 & $0.156^{* *}$ & $0.153^{* *}$ & $0.216^{* *}$ \\
\hline $\mathbf{i}$ & 0.002 & -0.012 & -0.005 & 0.050 \\
\hline j & 0.014 & $0.127^{* *}$ & $0.126^{* *}$ & $0.208^{* *}$ \\
\hline $\mathbf{k}$ & 0.007 & $0.076^{* *}$ & $0.061 *$ & 0.039 \\
\hline 1 & 0.015 & $0.155^{* *}$ & $0.163^{* *}$ & $0.290 * *$ \\
\hline m & -0.024 & $0.083^{* *}$ & 0.047 & $0.098^{* *}$ \\
\hline $\mathbf{n}$ & -0.001 & $0.181^{* *}$ & $0.139 * *$ & $0.272 * *$ \\
\hline $\mathbf{o}$ & 0.010 & $0.110^{* *}$ & $0.115^{* *}$ & $0.256^{* *}$ \\
\hline
\end{tabular}

${ }^{*} p<00.5 .{ }^{* *} p<0.01$. a: Ugly/beautiful; b: ordinary/special; c: artificial/natural; d: non-memorable/memorable; e: tiresome/relaxing; f: non-diverse/diverse; g: simple/complex; h: non-distinctive/distinctive; 1: uncolored/colorful; i: convenient/inconvenient; $\mathfrak{j}$ : not worth seeing/worth seeing; $\mathbf{k}$ : not applicable to every place/applicable to every place; 1 : not esthetic/esthetic; $\mathbf{m}$ : unreliable/reliable; $\mathbf{n}$ : incompatible/compatible; o: non-functional/functional. 1: Number of species; 2: design precision; 3: design color; 4: size.

Correlation analyses revealed that the size of the AGWs directed the perception of the design as beautiful, special, natural, memorable, relaxing, diverse, distinctive, colored, esthetic, worth seeing, reliable, compatible, and functional. An increasing number of species reduced the distinctiveness. The distinctive nature of the design allowed the user to perceive the place as beautiful, special, natural, memorable, relaxing, colored, esthetic, reliable, compatible, and functional. Regression analyses were performed to identify the variables significant in the visual assessment of the AGWs (Table 5).

Table 5. Results of regression analyses.

\begin{tabular}{|c|c|c|c|c|c|c|c|}
\hline \multicolumn{2}{|c|}{ Model Parameters } & $\mathbf{R}^{2}$ & B & $\beta$ & $\mathbf{t}$ & $\mathbf{F}$ & Materiality \\
\hline \multicolumn{2}{|c|}{ Constant } & \multirow{14}{*}{0.26} & 2.661 & & 6.398 & \multirow{14}{*}{36.24} & 0.000 \\
\hline \multirow{7}{*}{$\begin{array}{c}\text { Visual } \\
\text { Impact Adjective }\end{array}$} & Diversity & & 1.281 & 0.346 & 12.834 & & 0.000 \\
\hline & Esthetic & & 0.678 & 0.298 & 10.272 & & 0.000 \\
\hline & Chromaticity & & -0.202 & -0.087 & -2.455 & & 0.014 \\
\hline & Complexity & & -0.243 & -0.091 & -3.063 & & 0.002 \\
\hline & Applicability & & -0.239 & -0.065 & -2.451 & & 0.014 \\
\hline & Worth seeing & & 0.191 & 0.088 & 3.416 & & 0.001 \\
\hline & Natural & & 0.262 & 0.111 & 3.827 & & 0.000 \\
\hline \multirow{3}{*}{$\begin{array}{c}\text { Factor } \\
\text { Affecting Design }\end{array}$} & Plant diversity & & -0.192 & -0.082 & -2.436 & & 0.015 \\
\hline & Natural & & -0.228 & -0.088 & -3.440 & & 0.001 \\
\hline & Light & & 0.489 & 0.085 & 3.377 & & 0.001 \\
\hline \multirow{3}{*}{$\begin{array}{l}\text { Determination } \\
\text { in Design }\end{array}$} & No. of species & & 0.428 & 0.067 & 2.729 & & 0.006 \\
\hline & Size & & 0.318 & 0.055 & 2.230 & & 0.026 \\
\hline & Color & & -0.166 & -0.069 & -2.141 & & 0.032 \\
\hline
\end{tabular}

Regression analyses revealed that specified compositions were defined by 13 different factors: diversity $\left(R^{2}=0.26\right.$ and $\left.\beta=0.346\right)$, esthetic $(\beta=0.298)$, colorfulness $(\beta=-0.87)$, complexity $(\beta=-0.91)$, applicability $(\beta=-0.65)$, worth seeing $(\beta=0.88)$, naturalness $(\beta=0.111)$, plant diversity $(\beta=0.082)$, light $(\beta=0.085)$, number of species $(\beta=0.67)$, size $(\beta=0.55)$, and design colorfulness $(\beta=-0.69)$ $(p<0.001)$. Martin et al. [28] assessed visual perceptions for highways and surroundings and defined these with $R^{2}=0.70$. Eroğlu [26] performed a regression analysis for design criteria identifying visual impacts as well as for the variables defining composition on the basis of image groups with 
$\mathrm{R}^{2}=0.40$. In this study, $\mathrm{R}^{2}$ was defined as 0.26 . This value was found to be sufficient for the identification of variables significant in the visual assessments. According to the findings for the arithmetic mean, correlation analysis, and regression analysis, the participants perceived GWs as a natural area. The participants want to see GWs around them, and the perceivability of the GWs depends on their size, number of species, and color.

\section{Discussion and Results}

Ever-increasing urbanization and structuring to meet housing needs of migrating populations destroy green spaces and make cities uninhabitable places; there are also increasing land prices in city centers with limited space for housing, such as in the research provinces of İstanbul and Trabzon (Figure 5).

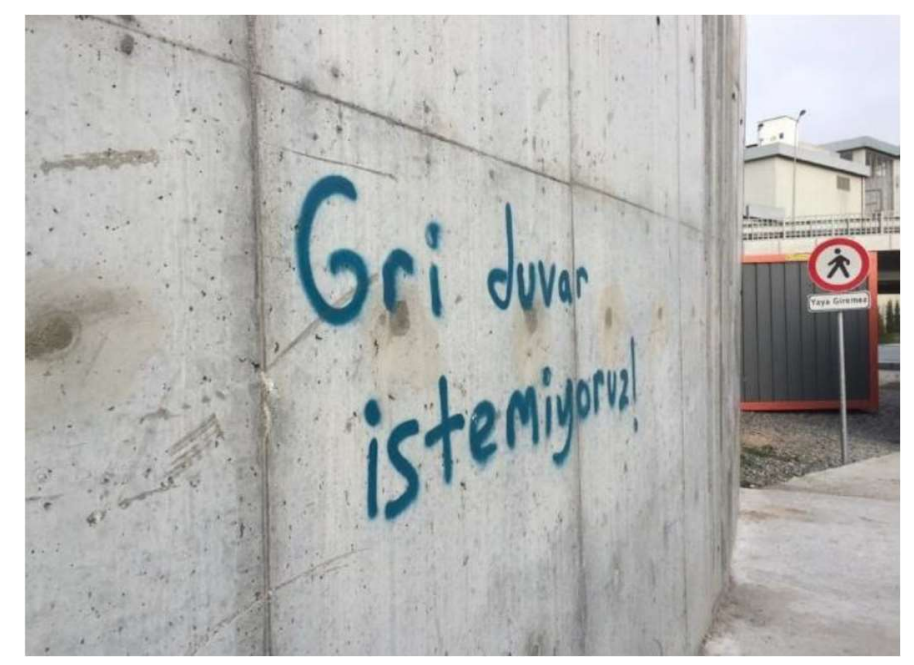

Figure 5. An image taken at research site able to put forth the reactions of the users. (“We don't want grey walls!").

When the A\&NGWs were compared with regard to physical attributes, vegetative covers, and establishment and maintenance costs, it was observed that establishment and maintenance of the AGWs were fairly troublesome. However, NGWs provide a comfortable ecological living atmosphere for city dwellers, and they can be established at somewhat cheaper costs because of natural vegetation species [33].

When the physical characteristics of the A\&NGWs were compared, it was observed that the initial establishment of AGWs was more troublesome and costly. Less and cheaper materials are generally used in the establishment of NGWs.

Considering the previous studies and field implementations based on these studies, it was determined that GWs established by using industrial materials and exotic plants had various problems with regard to sustainability and fairly high maintenance costs.

This study revealed the systemic and financial differences between A\&NGWs. It asserted that the sustainability of NGWs is easier to achieve than for AGWs. In addition, this study found controversy in that maintenance costs were more expensive than the contributions of AGWs to the heating and cooling costs.

Vegetal designs should have some characteristics to perform their expected functions [34]. Plants should be resistant to negative conditions to some extent, should be tolerant to varying conditions, and should be able to grow in limited mediums such as pots or containers. Plants should also preserve green herbage for long durations [13]. As its nature, natural vegetation hosts occasionally invasive species. This circumstance leads to a rivalry among species and also indicates a stage of succession in natural plant composition $[31,35,36]$. However, using non-native species that have an 
invasive character in natural habitats might cause natural vegetation suppression or disappearance. For this reason, it is important to take into consideration when using non-native species whether these species are invasive or not.

AGWs usually require more maintenance than GFs because of plant diversity, intensity, growth mediums, and positions. Precision of maintenance depends on the type of GW system and the type of plants used over the walls. Plants with greater nutritional needs require greater maintenance. The level of maintenance also influences the esthetic quality expected from the GW. Regular irrigation, nutrition and light requirements, pruning of fast-growing shrubby species, and reestablishment of the balance distorted by gravity are the primary maintenance practices [37]. NGW systems also need maintenance. However, NGW maintenance requires less effort. In order to reach the target as soon as possible, some measures need to be taken after the work is completed. Plant communities in natural systems are highly variable until they come to the condition of climax, and they pass through various metamorphosis stages. Therefore, the natural plants also need maintenance activities such as irrigation, fertilization, pruning, protection from harm, dead cover cleaning, and tillage until they reach the climax [38-40]. Maintenance activities can also be partially stopped after natural species climax.

The alkaline nature and high calcium content of municipal water may create a problem for base layers of GWs. Such conditions may exert serious threats on peat soils requiring a $\mathrm{pH}$ value of between 4.5 and 5.5. For healthy plants, nutrients require $\mathrm{pH}$ values of 6-7. Therefore, phosphoric fertilizers or high-acid fertilizers should be used to eliminate negative impacts of municipal water. Commercial 21-7-7 highly acidic NPK (Nitrogen, Phosphorus, Potassium) fertilizers could be recommended for this purpose [41]. GW systems should be inspected against pests and diseases in monthly periods and pesticide/insecticide treatments should be performed on scheduled dates. A maintenance program should be created to provide sustainability of GWs. In AGWs, regular fertilization will increase the nutrients in the soil to a large extent, and the risk of eutrophication will emerge. Therefore, irrigation and fertilization activities should be constantly monitored for prevent eutrophication. Soil moisture and plant nutrients must be kept under constant observation to ensure continuity. When the NGWs included in the survey were examined, there was no evidence of eutrophication that could affect the plant habitat. In this study, the disadvantages of GW maintenance and regular irrigation were considered, and the question of how to evaluate naturally grown species on wall surfaces with minimal cost and maintenance was discussed.

On the other hand, for the NGWs investigated in this study, plant species continuously regenerated because of vegetation durability, and all the species were indigenous species already adapted to the region in which they existed; therefore, they exhibited the same impacts all the time. Because the water requirements for the exotic plants used in AGWs vary on the basis of the seasons, they should continuously be monitored. However, there is no need for such an extra effort to provide sustainability of NGWs.

Besides irrigation, lighting is also a significant factor in achieving the desired performance or yield (stem, leaf, and flower appearance) of exotic plants used in AGWs. The determination of the distances of lighting systems from the plants and lighting durations requires extra effort. However, in NGWs, even $0-2 \mathrm{~h}$ sunshine durations may provide healthy vegetation.

Apart from irrigation and lighting, there are some other parameters to be considered for the sustainability of AGWs, such as the planting system and ecologic compliance of the plants.

Generally, epiphyte species are used when selecting plant species for AGWs [8]. Epiphyte species generally have fairly low soil requirements. The companies making GW applications in Turkey usually use certain species available from interior plant sellers [8]. Such a case can result in similarities in all designs but ecological incompliances among plant species. A GW that is not able to meet these criteria usually disappears in a short time. When the disadvantages of the GWs overcome the advantages, they have to be removed from the places in which they were established. However, in NGWs, already compatible species spread over the walls. Because the natural species 
alone are able to provide sustainability for both the GW and the vegetation, the ecological incompliance is automatically eliminated.

Despite the significance of selection of natural species for GWs, there were only two species in the present AGWs of $638 \mathrm{~m}^{2}$ (one species for $319 \mathrm{~m}^{2}$ ). On the other hand, there were 180 species identified over $2400 \mathrm{~m}^{2} \mathrm{NGWs}$ ( 1 species for $13 \mathrm{~m}^{2}$ ). While natural species were encountered only on $20 \%$ of the AGWs, they were encountered on $100 \%$ of the NGWs. In terms of plant abundance in the walls, while $1 \mathrm{~m}^{2}$ AGWs contained 6.4 native plants, $1 \mathrm{~m}^{2} \mathrm{NGWs}$ contained 36 native plants.

Besides the questionnaires, the images taken at the research site also revealed that walls should contribute to ecological structure together with their supportive and limiting functions.

To reduce high establishment and maintenance costs and to provide sustainability of vertical systems in urban places, NGWs should be preferred. However, it may be impossible to use NGWs in interior places. Improved Turkish plant species able to adapt interior places should be used in AGWs to reduce initial and maintenance costs. Such natural species also prolong the life of the GWs. Natural species provide different alternatives to limited species and may provide significant contributions for a healthy ecosystem [42].

The aim of the introduction of new concepts such as GWs and green roofs is ecological and economic sustainability. It is more accurate to evaluate the types of wall vegetation that are more efficient in terms of ecological desires for ensuring economic and ecological sustainability. Therefore, the economic performances of the green vertical planes were also investigated. The study "Cost-Benefit Analysis of Green Surfaces" that was conducted by Perrini and Rossasco [43] was examined. In the study, GWs were considered in three groups: NGWs that plants naturally or spontaneously climb; GF covered with plants supported by tulle and knitted wire systems; and AGWs, for which boxes are used on the wall surface because of the need for the growing plants to grow at different points on the wall surface. Water and nutrient requirements of plants are provided through industrial products.

Cost analyses for existing GW groups revealed that the cost was $€ 30-45$ per square meter for the walls with self-winder plants, $€ 40-75$ per square meter for the walls supported with wiring and mesh systems, $€ 800$ per square meter for the walls with the boxes installed over the walls to provide a growth medium, and $€ 1200$ per square meter for bio-walls or living walls [44].

Perrini et al. $[43,44]$ in a study determined the costs of AGWs. In the present study carried out in Turkey, cost tables were provided for the cheapest AGWs per square meter (GF, composed of winder plants) (Table 6) and the most expensive AGW per square meter (living walls composed of industrial products) (Table 7).

Table 6. Cost table for green façade (GF) $\left(10 \mathrm{~m}^{2}\right)$.

\begin{tabular}{|c|c|c|c|c|c|c|}
\hline Item No. & Pose No. & Type of Manufacturing & Unit & Amount & Unit Price $(€)$ & Total Price $(€)$ \\
\hline 1 & $04.278 / 3 \mathrm{~F}$ & Galvanized wire & $\mathrm{kg}$ & 100.00 & 0.66 & 66.00 \\
\hline 2 & $04.435 / 10 \mathrm{~A}$ & $\begin{array}{l}\text { Mortared anchor }(\text { bar })(5 \times 150 \mathrm{~mm} \text { diameter }) \\
\text { (stainless cutting } 304)\end{array}$ & Piece & 60.00 & 0.09 & 5.40 \\
\hline 3 & VG.1 & $\begin{array}{l}\text { Ivy (average price is written with reference to } \\
\text { species such as Vitis vinifera, Hedera helix, } \\
\text { Wisteria sinensis, Campsis radicans, Humulus } \\
\text { lupulus, Clematis vitalba, and Vicia cracca } \\
\text { involved in research areas) }\end{array}$ & Piece & 50.00 & 2.00 & 100.00 \\
\hline 4 & VG.2 & $\begin{array}{l}\text { Maintenance costs (annual cost of irrigation and } \\
\text { fertilization) }\end{array}$ & Piece & 1.00 & 75.00 & 75.00 \\
\hline \multirow[t]{2}{*}{5} & Y.23.176 & $\begin{array}{l}\text { Making various ironworks from sheet and } \\
\text { profile iron and putting them in their position }\end{array}$ & $\mathrm{kg}$ & 50.24 & 1.98 & 99.47 \\
\hline & & & & & Total & $€ 345.87$ \\
\hline
\end{tabular}

Table was prepared with E-Hakdediş software; prices were taken from 2017 Unit Price Handbook of Ministry of Environment and Urbanization. The prices not available in this handbook were determined from the invoices and are marked as VG (vertical garden) in table. Vegetation prices were determined as the average price of eight different plant species encountered in research site. 
Cost analyses for the GF revealed a cost of $€ 34.87$ per square meter. It was determined that this method was the cheapest method for the production of man-made GWs.

Table 7. Cost table for living walls $\left(10 \mathrm{~m}^{2}\right)$.

\begin{tabular}{|c|c|c|c|c|c|c|}
\hline Item No. & Pose No. & Type of Manufacturing & Unit & Amount & Unit Price $(€)$ & Total Price $(€)$ \\
\hline 2 & $04.769 / 09$ & $\begin{array}{l}\text { Every kind of hard PVC (Polyvinyl Chloride) } \\
\text { plastic sheet }\end{array}$ & $\mathrm{kg}$ & 236.76 & 0.33 & 78.13 \\
\hline 3 & $1001-571$ & Pressure regulator for type A and B hydrants & Piece & 1.00 & 37.00 & 37.00 \\
\hline 5 & 204-101 & $\begin{array}{l}\text { Hard PVC drinking water pipe (adhesive tie; } \\
\text { diameter: } 20 \mathrm{~mm} \text {; } 10 \text { ATS) }\end{array}$ & $\mathrm{m}$ & 20.00 & 0.34 & 6.80 \\
\hline 6 & Y.23.176 & $\begin{array}{l}\text { Making and replacing various ironworks from } \\
\text { lama and profile iron }\end{array}$ & $\mathrm{kg}$ & 114.24 & 1.99 & 227.34 \\
\hline 7 & IVG.1 & Drip irrigation pipe (paved with $50 \mathrm{~cm}$ intervals) & $\mathrm{m}$ & 20.00 & 0.63 & 12.60 \\
\hline 10 & IVG.4 & Fertilizer tank (100 L) & Piece & 1.00 & 72.25 & 72.25 \\
\hline 11 & IVG.5 & Fertilizer pump & Piece & 1.00 & 118.75 & 118.75 \\
\hline 12 & IVG.6 & Timer & Piece & 1.00 & 80.00 & 80 \\
\hline 13 & IVG.7 & Fogging pump (in combination with nozzle) & Piece & 1.00 & 701,25 & 701.25 \\
\hline 14 & IVG.8 & Lime ionizer & Piece & 1.00 & 87.50 & 87.50 \\
\hline 15 & IVG.9 & Drain duct (in combination with filter) & Piece & 1.00 & 95.00 & 98.00 \\
\hline 16 & IVG.10 & Lighting system (Agrotip applied with lamps) & Piece & 1.00 & 312.50 & 312.50 \\
\hline 17 & IVG.11 & $\begin{array}{l}\text { Maintenance costs (annual cost of irrigation and } \\
\text { fertilization) }\end{array}$ & Piece & 1.00 & 362.50 & 362.50 \\
\hline
\end{tabular}

Table was prepared with E-Hadediş software; prices were taken from 2017 Unit Price Handbook of Ministry of Environment and Urbanization. The prices not available in this handbook were determined from the invoices and are marked as IVG (industrial vertical garden) in table. Vegetation prices were determined as the average price of 49 different plant species encountered in research site.

Cost analyses for living walls revealed a cost of $€ 415.649$ per square meter. It was determined that living walls were the most expensive type of man-made GW. Considering the costs of two wall systems, it was observed that a GF could be established with about 12.01 of the cost of living walls.

The natural wall presented in Figure 6 had the greatest number of species. It was observed that the walls were able to convey the water behind to the wall to the wall surface, and the walls with joints were able to provide nutrients to the plants that had greater vegetation densities. Niches to be constructed over the artificial walls to provide a nutrient medium and to hold water will provide significant contributions to form natural vegetation, will minimize the cost of vegetation exchange, and ultimately will provide sustainability of the vegetation of the AGWs.

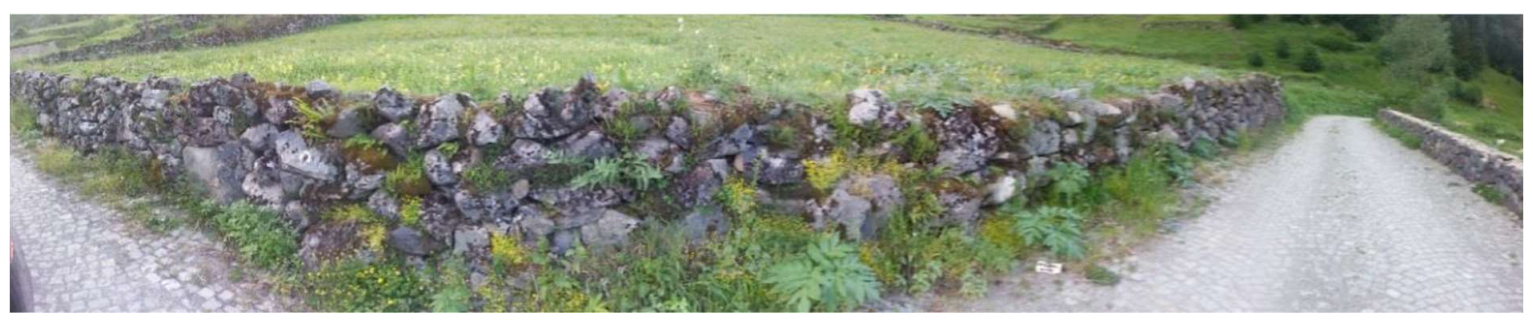

Figure 6. Natural wall vegetation in research area. 
Author Contributions: Conceptualization, A.M., N.B., E.Y., and E.E.; Methodology, A.M., N.B., E.Y., and E.E.; Software, A.M., N.B., E.Y., E.D., M.K.A., and E.E.; Validation, E.Y., and E.E.; Formal Analysis, A.M., N.B.; Investigation, E.Y., M.K.A., and E.E.; Resources, A.M., N.B.; Data Curation, A.M., N.B. and E.D.; Writing-Original Draft Preparation, A.M., N.B., E.Y., E.D., M.K.A., and E.E.; Writing-Review \& Editing, E.Y. and E.E.; Visualization, A.M., N.B., E.D.; Supervision, E.Y. and E.E.; Project Administration, A.M., N.B., E.Y. and E.E.

Funding: This research received no external funding.

Conflicts of Interest: The authors declare no conflict of interest.

\section{References}

1. Helzel, M. Paslanmaz Çelikten Yapılmış Yeşil Duvarlar; Bina Serisi, 2012; Euro Inox: Mortara, Italty, 2012.

2. Köhler, M. Green Facades-A View Back and Some Visions. Urban Ecosyst. 2008, 11, 423-436. [CrossRef]

3. Yalçınalp, E.; Meral, A. Wall Vegetation Characteristics of Urban and Sub-Urban Areas. Sustainability 2017, 9, 1691.

4. Yalçınalp, E.; Özveren, S.; Meral, A.; Pulatkan, M.; Akbulut, S. Habitat Effect on Urban Roof Vegetation. Sustainability 2017, 9, 1985.

5. Loh, S. Living Walls: A Way to Green the Built Environment. In Environment Guide Technology; Australian Institute of Architect: Melbourne, Australia, 2008.

6. Matthews, J.; Winter, M. Multi Tired Vine Park; Raderschall Landschaftsarchitekten Ag: Zurich, Switzerland, 2009.

7. Dunnett, N.; Kingsbury, N. Planting Green Roofs and Living Walls; Timber Press: Portland, OR, USA, 2008.

8. Blanc, P. The Vertical Garden from Nature to the City; W.W. Norton \& Company: New York, NY, USA, 2008.

9. Bjerre, A.L. Green Wall; Report of Architect Education; VIA University: Horsens, Denmark, 2011.

10. Yeh, Y.P. Greenwall: The Creative Solutions in Response to the Urban Heat İsland Effect; Ulusal Chung-Hsing University: Taichung City, Taiwan, 2010.

11. Meral, A. Peyzaj Mimarlığ Kapsamında Kentsel ve Kırsal Duvar Vejetasyonu ve Ekolojik Karakteristikleri. Master's Thesis, Karadeniz Teknik Üniversitesi, Fen Bilimleri Enstitüsü, Trabzon, Turkey, 2015.

12. Mir, M.A. Green Facades and Building Structures. Master's Thesis, Delft University of Technology, Delft, The Netherlands, 2011.

13. Başaran, N. İç Mekan Dikey Bahçelerinin İrdelenmesi İstanbul ve Çevresi Örneği. Master's Thesis, Düzce Üniversitesi Fen Bilimleri Enstitüsü, Düzce, Turkey, 2016.

14. Bass, B.; Baskaran, B. Evaluating Rooftop and Vertical Gardens as an Adaptation Strategy for Urban Areas; National Research Council Canada: Ottawa, ON, Canada, 2003.

15. Jim, C.Y. Old Stone Walls as an Ecological Habitat for Urban Trees in Hong Kong; University of Hong Kong: Hong Kong, China, 1998.

16. Mattheck, C.; Breloer, H.; Bethge, K. A Guide to Fractometer Tree Assessment. Arborist News 1994, 3, 9-12.

17. Lima, A.B. The Vertical Garden; Mission Hills Garden Clup: San Diego, CA, USA, 2011; pp. 14-16.

18. Doernach, R. Pflanzenfassaden Pflanzenklimateppiche Energiesparer: Biotektur; Ökojurnal. No: 4/5; Hafencity Universität Hamburg: Hamburg, Germany, 1978.

19. Ayaşligil, Y. Ecology and Natural Distribution of Woody plants that can be used in parks and gardens. J. For. Fac. 1990, 39, 1.

20. Akman, Y.; Ketenoğlu, O. Vejetasyon Ekolojisi (Bitki Sosyolojisi); Ankara Üniversitesi Basımevi: Ankara, Turkey, 1987.

21. Segal, S. Notes on Wall Vegetation; Dr. W. Junk: The Hague, The Netherlands, 1969.

22. Darlington, A. Ecology of Walls; Heinemann: London, UK, 1981.

23. Duchoslav, M. Flora and Vegetation of Stony Walls in East Bohemia; Czech Botanical Society: Prague, Czech Republic, 2002.

24. Jim, C.Y.; Wendy, Y.C. Habitat Effect on Vegetation Ecology and Occurrence on Urban Mansory Walls. Urban Dorestry Urban Green. 2010, 9, 169-178. [CrossRef]

25. Tong, J. Living Wall: Jungle the Concrete; Design Media Publishing Limited: London, UK, 2013.

26. Eroğlu, E. Dağlik Alan Yol Koridorlarinda Peyzaj Karakterini Belirleyen Doğal Bitki Kompozisyonlarinin Tanimlanmasi. Ph.D. Thesis, Karadeniz Teknik Üniversitesi, Trabzon, Turkey, 2012. 
27. Penning, E.; Rowsel, C. The Social Value of Engilish Landscape. In Proceedings of the Conference on Aplied Tecniques or Analysis and Manegement of the Resource, Incline Village, NV, USA, 23-25 April 1979; pp. 249-255.

28. Misgav, A. Visual Preference of the Public for Vegetation Groups in Israel. Landsc. Urban Plan. 2000, 48, 143-159. [CrossRef]

29. Osgood, C.E.; Suci, G.J.; Tannenbaum, P.H. The Measurement of Meaning; University of Illinois Press: Champaign, IL, USA, 1957; Volume 48, pp. 143-159.

30. Özgen, Y. Doğu Karadeniz Bölgesi’de Ordu-Rize Arası Kıyı Yolunun Peyzaj Özellikleri, Peyzaj Mimarlı̆̆ı Açısından Ortaya Koyduğu Sorunlar ve Çözümü Üzerine Bir Araştırma; İstanbul Üniversitesi Orman Fakültesi Dergisi: İstanbul, Turkey, 1984; p. 2.

31. Eroğlu, E. Düzce Kenti Açık ve Yeşil Alanlardaki Bazı Bitki ve Bitki Gruplarının Mevsimsel Değşim Potansiyelinin Bitkisel Tasarım Yönünden Incelenmesi. Master's Thesis, Abant İzzet Baysal Üniversitesi, Bolu, Turkey, 2004.

32. Raunkiaer, C. The Life Forms of Plants and Statistical Plant Geography; Oxford University Press: London, UK, 1934.

33. Martin, B.; Loro, M.; Arce, R. Landscape around motorways. In Proceedings of the Energy Future the Role of Impact Assessment 32nd Annual Meeting of the International Association for Impact Assessment, Porto, Portugal, 27 May-1 June 2012.

34. Baturlar, F. İç Mekanlarda Bitki Kullanımının Estetik Ve Fonksiyonel Özellikler Yönünden İrdelenmesi. Master's Thesis, Mustafa Kemal Üniversitesi, Fen Bilimleri Enstitüsü, Antakya, Turkey, 2011.

35. Acar, C. Trabzon ve Çevresinde Yetişen Doğal Bazı yer Örtücü Bitkilerin Peyzaj Mimarlığında Değerlendirilmeleri Üzerine bir Araştırma. Ph.D. Thesis, K.T.Ü. Fen Bilimleri Enstitüsü, Trabzon, Turkey, 1997.

36. Diekelmann, J.; Schuster, R. Natural Landscaping Designing with Native Plant Communities; University of Wisconsin Press: Wisconsin, WI, USA, 2002.

37. Ürgenç, S. Ağaç ve Süs Bitkileri Fidanlık ve Yetiştirme Tekniği; Üniversite yayın No: 3676. Fakülte yayın No: 418; İstanbul Üniversitesi Basımevi ve Film Merkezi: Istanbul, Turkey, 1992.

38. Görcelioğlu, E. Peyzaj Onarım Tekniğĭ İstanbul Üniversitesi Orman Fakültesi Yayınları: İstanbul, Turkey, 2002.

39. Rietbergen, J.M.; Maginnis, S.; Sarre, A. The Forest Landscape Restoration Handbook; Earthscan: London, UK, 2007.

40. Tormo, J.; Bochet, E.; García-Fayos, P. Road Slope Revegetation in Semiarid Mediterranean Environments. Part II: Topsoling, Species Selection and Hydroseeding. Restor. Ecol. 2007, 15, 97-102. [CrossRef]

41. Cooney, E.; Deller, S.; Michie, L.; Wedderburn, D. A Research Study of the Feasibility of Implementing a Living Wall into the Environmental Studies 2 Building; ERS 250; University of Waterloo: Waterloo, ON, Canada, 2004.

42. Başaran, N.; Eroğlu, E. İç Mekan Dikey Bahçe Bitki Kompozisyonlarının Görsel Peyzaj Kalitesinin Değerlendirilmesi. J. For. 2017, 12, 1-18.

43. Perrini, K.; Rosasco, P. Cost-Benefit Analysis for Green Façades and Living Wall Systems. Build. Environ. 2013, 70, 10-121. [CrossRef]

44. Perrini, K.; Ottelé, M.; Haas, E.; Raiteri, R. Greening the Builging Envelope, Façade Greening and Living Wall Systems. Open J. Ecol. 2011, 1, 1-8. [CrossRef]

(C) 2018 by the authors. Licensee MDPI, Basel, Switzerland. This article is an open access article distributed under the terms and conditions of the Creative Commons Attribution (CC BY) license (http://creativecommons.org/licenses/by/4.0/). 